\title{
Genetic Variability, Character Association, Frequency and Normality Distribution Studies for F2 Population of BPT-5204 x WAB-450 Cross in Rice (Oryza sativa L.)
}

\author{
M. B. Boranayaka ${ }^{1}$, R. Lokesha ${ }^{2}$, H. C. Latha ${ }^{3}$ and K. Mahanth Shivayogayya ${ }^{3}$ \\ ${ }^{1}$ Dr. M. B. Boranayaka, AICRP (Sorghum), RARS, Vijayapur-586101, India \\ ${ }^{2}$ Department of Genetics and Plant breeding, UAS Raichur-586101, Karnataka, India \\ ${ }^{3}$ Department of Agricultural Entomology, UAS Raichur-586101, Karnataka, India
}

*Corresponding author

\begin{tabular}{|c|c|}
\hline & A B \\
\hline & \multirow{8}{*}{ 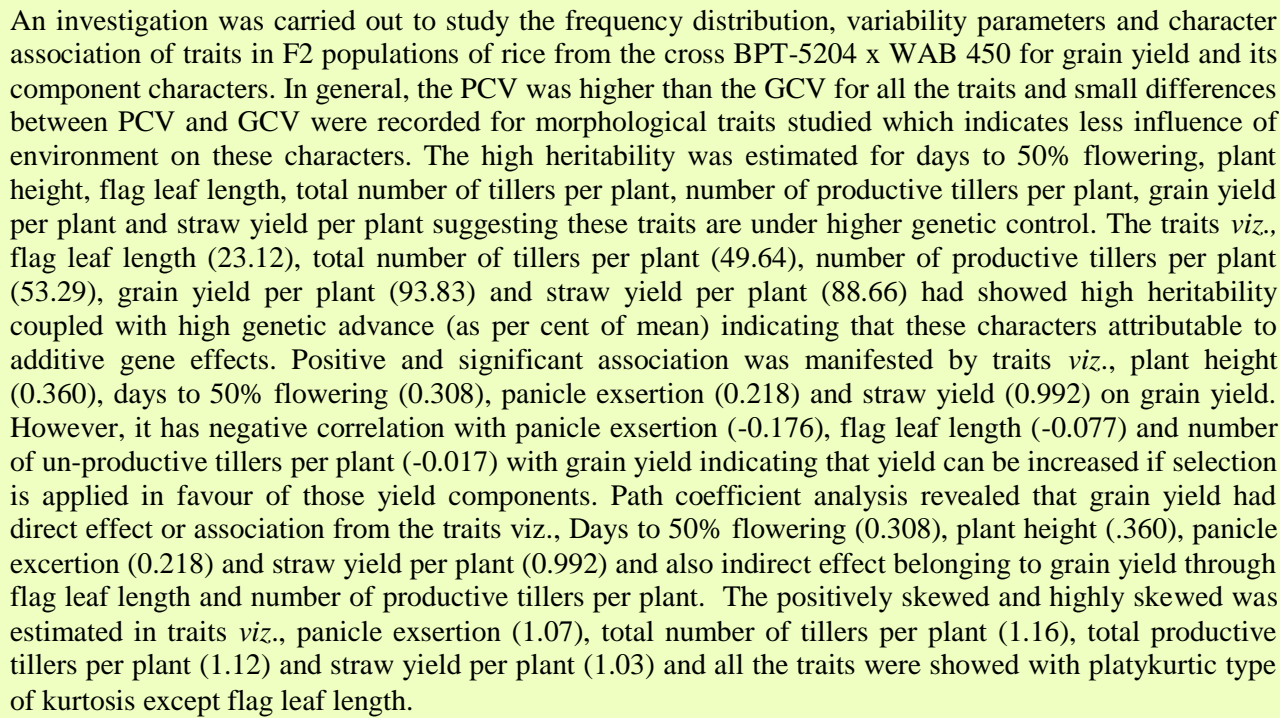 } \\
\hline & \\
\hline $\begin{array}{l}\text { Rice, F2 population, } \\
\text { Skewness and }\end{array}$ & \\
\hline Kurtosis, & \\
\hline & \\
\hline Article Info & \\
\hline $\begin{array}{l}\text { Accepted: } \\
\text { 05 April } 2020 \\
\text { Available Online: } \\
10 \text { May } 2020\end{array}$ & \\
\hline & \\
\hline
\end{tabular}

\section{Introduction}

Rice (Oryza sativa L.) has a renowned relationship with the human since ages. It is the world's second most widely grown cereal crop after wheat and presently, more than half of the world's population depends on it as a staple diet. 'Rice is life' for human beings especially in Asian subcontinent, Asia can be considered as "Rice Basket" of the world, as 90 per cent of world's rice is grown and consumed with 60 per cent of population and 
where, about two-thirds of world's poor live (Khush and Virk, 2005). Only 4-5 per cent of world rice production enters the global market. Hence, any shortfall in rice production especially in the major rice growing countries could be disaster for food security.

The high level of genetic heterogeneity is possessed by our traditional rice varieties or landraces compared to modern cultivars. Local cultivars or landraces comprise of the unique source for gene of high adaptability but are poor yielders.

Therefore, it is an indispensable demand for varietal improvement in such situation. To formulate a sustainable breeding program precise knowledge about genetic divergence for yield components is a crucial one as varietal improvement depends mainly on the selection of parents with high genetic divergence in hybridization.

Crop improvement for specific trait has been achieved through effective use of F2 segregating population and fixing desirable combinations (Mamatha et al., 2018). Therefore, the present study has been undertaken to determine the estimates of variability, heritability and genetic advance as per cent of mean for grain yield and its component and frequency distribution pattern based on skewness and kurtosis in F2 segregating generation for BPT 5204 and WAB-450 cross combination.

\section{Materials and Methods}

The present investigation was carried out from 2012 to 2014, at UAS Raichur, Agricultural Research Station, Gangavati, representing the Northern dry zone which is located at latitude of $15^{\circ} 43^{\prime}$ North and longitude of $76^{0} 53$ ' East and altitude of 406 meters above Mean Sea Level (MSL).

\section{Plant material}

In this experiment, the crossing work was carried out to develop population(s) in the background of BPT5204 variety which has been grown from many years and has occupied more than 90 per cent area under Tungabhadra river command area of India. It is a fine grain and long duration variety maturing in about 150-160 days. It has acceptable consumer quality and hence fetches high price in the market.) and WAB450 (Interspecific line derived from Oryza glaberrima and Oryza sativa at Africa Rice Centre, WARDA) used as a donor variety for traits of interest under study.

\section{Crossing programme and raising $\mathrm{F}_{1} \mathrm{~S}$}

The above mentioned BPT 5204 and WAB450 genotypes were used as parental genotypes to derive $\mathrm{F}_{1} \mathrm{~s}$ during Kharif 2012. Staggered sowing of the parental genotypes was done to achieve synchronization in the flowering event for effective crossing programme. The seedlings were raised by following all the recommended agronomic practices. At panicle emergence and flowering stage, the florets in panicles of female parents were hand emasculated early in the morning, before $7 \mathrm{a} . \mathrm{m}$. and later the pollen was collected from male parent and dusted on to the stigma within 11:15 a.m. for effective pollination and fertilization. (Pictorial view of crossing programme with tools used presented in the Figure 1.)

The seed set in the female plant and male plants were collected, dried and stored after maturity. Especially in the female plant, the seeds formed due to crossing were harvested, around 25 to 30 days after crossing event. The seeds obtained from crossing (seed set in the female plant) are used further to raise $F_{1}$ seedlings. The $\mathrm{F}_{1} \mathrm{~s}$ were raised in pots under greenhouse condition and then transplanted 
into main filed during Kharif 2013 at ARS, Gangavati, UAS, Raichur.

\section{Raising $\mathrm{F}_{2}$ population}

The $F_{2}$ seeds of all the crosses along with their parents were sown in the nursery bed and used to raise $F_{2}$ generation. Seeds were collected from a single $F_{1}$ plant and used to raise $\mathrm{F}_{2}$ generation during kharif 2014 .

All the $309 \quad F_{2}$ individuals selected were subjected for phenotypic evaluation for their yield and yield attributing traits. Observations on days to 50 per cent flowering, plant height, flag leaf length, flag leaf width, number of tillers, number of productive tillers, number of un-productive tillers per plant, panicle exsertion, grain yield, straw yield, number of grains, 1000 grain weight/test weight were recorded as described earlier in the Experiment-I. All the $309 \mathrm{~F}_{2}$ individuals of the crosses were selfed and seeds collected from individual $F_{2}$ plants were used to raise $F_{3}$ in generation.

\section{Statistical analysis}

The statistical analysis of the data on individual characters using AGRISTAT package was carried out on the mean values of each genotypes and checks. Different statistical methods employed for the analysis are presented below:

\section{Analysis of variance (ANOVA)}

The analysis of variance as per Federer (1977) was carried out for different characters in order to assess the variability among the genotypes. The significance was tested by comparing with the table values as given by Yates (1965). Standard error of means (SEM) and Co-efficient of variation (CV) were worked out using appropriate formula for comparing individual line means.

\section{Estimation of genetic variability parameters}

The co-efficient of variability (CV) both at phenotypic and genotypic levels for all the characters were analyzed by applying the formula suggested by Burton and De Vane (1953). PCV and GCV were classified as given by Robinson et al., 1949.

\section{Heritability (broad sense)}

Heritability in broad sense $\left(\mathrm{h}^{2}\right)$ estimates was computed by the formula suggested by Hanson et al., (1956). The heritability percentage was categorized as suggested by Robinson et al., (1949) as mentioned below:

$\begin{array}{ll}0-30 \text { per cent } & \text { Low } \\ 30-60 \text { per cent } & \text { Moderate } \\ 60 \text { per cent and above } & \text { High }\end{array}$

\section{Genetic advance (GA)}

The extent of genetic advance expected through selection for each of the character was calculated as per the formula suggested by Johnson et al., (1955). Intensity of selection as given by Lush, 1949.

\section{Genetic advance as per cent mean}

The genetic advance as per cent of mean was categorized as suggested by Johnson et al., (1955) and the same is given below:

$\begin{array}{ll}0-10 \text { per cent } & \text { Low } \\ 10-20 \text { per cent } & \text { Moderate } \\ 20 \text { per cent and above } & \text { High }\end{array}$

\section{Correlation analysis}

To estimate the degree of association between the traits studied, phenotypic correlation was computed by using the formula given by Webber and Moorthy (1952). The significance of correlation co-efficient was 
tested by referring to the table value at $n-2 \mathrm{df}$ given by Cochran and Snedecor (1961).

\section{Results and Discussion}

Success of any plant breeding programme depends on the extent of variability present in crop. The presence of genetic variability for economic trait is a key factor improving the local adopted varieties with regard to specific traits. Incidentally the parental lines used for developing mapping populations were also divergent for many of the trait related to productivity. Therefore, an effort was made to estimate variability and other related parameters for yield and yield components and also associated study have presented as follow.

\section{Mean performance and variability for yield and yield related components}

The mean performance, range, standard deviation (SD), standard error (SE), variance, skewness and kurtosis for all the traits studied in $F_{2}$ population individuals along with mean of parents and checks were presented in Table 1. Genetic parameters of $F_{2}$ individual plants of BPT $x$ WAB450 cross for yield and yield attributing characters was presented in Table 2. The frequency distribution for yield and yield attributing component traits in $\mathrm{F}_{2}$ segregation population of BPT5204 $\mathrm{x}$ WAB450 were given in Figure 2. Results of the present investigation were presented as follow.

\section{Days to $50 \%$ flowering}

The mean value for days to 50 per cent flowering among $\mathrm{F}_{2}$ individuals was 102.93 days. WAB 450, a donor parent and line BWL49 showed minimum days to flowering of 89 days. Line BW-L37 (116 days) showed maximum days to flowering. The estimate of GCV (7.058\%) and PCV (18.721) were low.
Low heritability $(1.00 \%)$ coupled with low genetic advance as percent of mean $(0.548 \%)$ was observed for this trait.

\section{Plant height (cm)}

Mean value of plant height among F2 individuals was $101.94 \mathrm{~cm}$. The minimum value observed was $77 \mathrm{~cm}$ in BPT5204 and line BW-L49, and maximum value observed was $119.75 \mathrm{~cm}$ in parent, WAB450. Low GCV (6.858\%), PCV (6.877\%) and high heritability (99.4\%) and genetic advance as percent mean $(14.089 \%)$ was observed in the population.

\section{Panicle length $(\mathrm{cm})$}

Length of the panicle observed was 22.29 with a range of 14.45 (BPT5204) to $27.0 \mathrm{~cm}$ (BW-L27) among $\mathrm{F}_{2}$ individuals. Moderate GCV (11.63\%), PCV (16.01\%) and moderate heritability (49.10\%) and Genetic advance as percent of mean $(16.79 \%)$ was observed in the population.

\section{Panicle exsertion $(\mathrm{cm})$}

The mean panicle exsertion observed was $2.63 \mathrm{~cm}$ with a range of 0.0 (zero) in some lines to maximum of $8 \mathrm{~cm}$ in line BW-L97. Moderate GCV (14.7\%), PCV (18.57\%) and moderate heritability (37.8\%) and Genetic advance as percent of mean $(17.409 \%)$ was observed in $\mathrm{F}_{2}$ individuals.

\section{Number of tillers per plant}

The average number of tillers per plant among the $\mathrm{F}_{2}$ population was 11.22 and it ranged from 5(BW-L31) to 19(BW-L67). Moderate GCV (24.14\%) and PCV (24.19\%) were observed. High heritability $(99.6 \%)$ and high genetic advance as percent of mean (49.64\%) was noticed for this population. 


\section{Number of productive tillers per plant}

Number of productive tillers per plant varied from to 3 to 18 in lines BW-L45 and BW-L31 among F2 individuals respectively. Mean value for this character found to be 9.77 . The estimates of GCV and PCV were $29.72 \%$ and $34.15 \%$ respectively. High heritability $(75.80 \%)$ coupled with high genetic advance as percent of mean $(53.29 \%)$ was observed for this character.

\section{Flag leaf length $(\mathrm{cm})$}

Considerable variation among $\mathrm{F}_{2}$ individuals observed for flag leaf length character with minimum of $19.0 \mathrm{~cm}$ in line BW-L20 and maximum of $35.0 \mathrm{~cm}$ in lines BW-L44 and WB-L75. Mean value $27.03 \mathrm{~cm}$ was recorded. Estimates of PCV and GCV were $12.30 \%$ and $13.49 \%$. High heritability $(83.2 \%)$ coupled with moderate GAM (23.13\%) was observed for this character.

\section{Flag leaf width $(\mathrm{cm})$}

Flag leaf width was ranged from $1.2 \mathrm{~cm}$ in line BW-L42 to $2.5 \mathrm{~cm}$ in line BW-56 among $\mathrm{F}_{2}$ individuals and had mean value of 1.56 $\mathrm{cm}$. Moderate GCV and high PCV were found to be $14.43 \%$ and $15.84 \%$ respectively. Very low heritability $(1.06 \%)$ coupled with very low genetic advance as percent of mean $(3.81 \%)$ were observed for this character.

\section{Grain yield per plant (g)}

Regarding grain yield/plant, the $\mathrm{F}_{2}$ population recorded the mean value of $28.05 \mathrm{~g}$ per plant with a range varied between from $9.50 \mathrm{~g}$ (BW-L29) to $73.50 \mathrm{~g}$ (BW-L40). High GCV $(45.60 \%)$ and PCV (45.66\%) were observed. Whereas, high heritability (99.8\%) and high GA as per cent mean (93.83\%) was recorded in the population.

\section{Straw yield per plant (g)}

The straw yield per plot was ranged in between15.68 (BW-L29) and 110.25g (BWL40) with a mean yield of $42.25 \mathrm{~g}$. The high GCV (43.83\%) and PCV (44.64\%) with high heritability (96.4\%) and GA as per cent mean $(88.66 \%)$ were observed.

The traits studied in the present investigation exhibited low, moderate and high PCV and GCV values. In the present study, the estimates of PCV were slightly higher than the corresponding GCV estimates and small differences between PCV and GCV recorded for morphological traits studied indicating that the portion of PCV was more contributed by the genotypic component and less influenced by the environment. Therefore, selection on the basis of phenotype alone can be effective for the improvement of these traits.

In the present study high estimates of PCV and GCV were observed for the traits viz., total number of tillers per plant, number of productive tillers per plant, grain yield per plant and straw yield per plant (Table 2).

These kinds of results also noticed for the studied traits by Savitha and Ushakumari (2015), El-Badri et al., (2016), Hefena et al., (2016), Rani et al., (2016) and Manjunatha et al., (2018). Similar findings were also supported by Arpita et al., (2014); Priyanka et al., (2011) for flag leaf area; Ashok et al., (2013) for 1000 grain weight and Kiran et al., (2012) for number of tillers per plant, number of productive tillers per plant and grain yield per plant.

The traits exhibiting high GCV and PCV indicating prominent variation or substantial amount of genetic variability presents in the population for the concerned trait and hence, there is scope for selection. 
In the present study, an estimated of moderate PCV values was exhibited by days to $50 \%$ flowering, panicle length, panicle exsertion, flag leaf length, flag leaf width and number of un productive tillers per plant while, low PCV value was shown by only by plant height trait. Similarly trend was also followed for GCV values except for days to $50 \%$ flowering which was shown low GCV value. This suggests that the genetic improvement through selection for these traits may not be always effective. Similar results obtained by Khare et al., (2014), Arpita et al., (2014) for days to maturity and days to 50 per cent flowering; Laxuman et al., (2010) for days to fifty percent flowering and Bekele et al., (2013) for days to maturity. These findings were in consonance with the reports made by Bhadru et al., (2012); Prajapathi et al., (2011); Singh et al., (2011) and Ananadarao et al., (2011) earlier in rice for days to $50 \%$ flowering, plant height and panicle length.

The high heritability estimates for exhibited traits suggesting these traits are under higher genetic control. High heritability (in broad sense) was noted for plant height similar to results shown by Padmaja et al., (2008); Umesh et al., (2015); Bhuvaneswari et al., (2015) and Shashidhara et al., (2017), panicle length similar to reports of Ogunbayo et al., (2014); Shrivastava et al., (2015) and Shashidhara et al., (2017), yield per plant similar to reports of Padmaja et al., (2008); Augustina et al., (2013 and Bhuvaneswari et al., (2015) and 100-grain weight similar to results shown by Padmaja et al., (2008). Ansari et al., (2004) stated that high heritability percentage reflects the large heritable variance which may offer the possibility of improvement through selection and similar results were also reported by Priyanka et al., (2011) for plant height, days to $50 \%$ flowering and flag leaf length and Padmaja et al., (2008), karthikeyan et al., (2010) and Khare et al., (2014) for test weight, plant height and days to 50 per cent flowering. Ashok et al., (2013) and Kole and Hasib (2008) for days to 50\% flowering and plant height, Kundu et al., (2008) for 1000 grain weight.

While, moderate heritability was estimated for panicle length and panicle exsertion but low heritability was recorded for the traits flag leaf width and number of unproductive tillers per plant. The moderate heritability was noted for days to flowering (60 percent), days to maturity (40percent) as given by Abebe et al., (2017); number of tiller per plant (65 percent); panicle no. per plant as reported by Ogunbayo et al., (2014) and spikelet fertility percentage by Umesh et al., (2015). The low heritability showed by flag leaf width and number of unproductive tillers per plant which indicates greater role of environment on the expression of the traits, thus, direct selection for these traits will be ineffective.

Genetic advance was recorded high for the traits viz., grain yield and straw yield while remaining all the traits showed with low genetic advance at $5 \%$. These traits indicate the predominance of additive gene effects in their expression and would respond to selection effectively as they are least influenced by environment. Johnson et al., (1955) reported that heritability estimates together with genetic advance are more important than heritability alone to predict the resulting effect of selecting the best individuals.

These findings were in accordance with the reports made earlier in rice by Bhadru et al., (2012), Arpita et al., (2014) and Parameshwar et al., (2015) for in1000 grain weight and average flag leaf length, Rema Bai et al., (1992) and Priyanka et al., (2011) for flag leaf length. Heritability alone provides no indication of the amount of genetic improvement that would result from 
selection of individual genotypes. Hence, knowledge about heritability coupled with genetic advance is most useful. In the present study, the traits viz., flag leaf length, total number of tillers per plant, number of productive tillers per plant, grain yield per plant and straw yield per plant had showed high heritability coupled with high genetic advance (as per cent of mean) indicating that these characters attributable to additive gene effects. These results were in accordance with the earlier findings of Anilkumar (2008) and Sangeetha (2013).

The aforesaid points revealed additive gene action and showed the possibility of selection per se in these crosses for the improvement of number of productive tillers per plant and the traits were under the control of additive gene action and this was in accordance with Sala, (2012) and Sangeetha, (2013). Hence selection for this trait was effective for improvement through selection.

Similar results were also reported by Pratap et al., (2012), Gangashetty et al., ((2013) and Khare et al., (2014). While, moderate GA as $\%$ mean was recorded for plant height, panicle length and panicle exsertion followed by low GA as per cent of mean was recorded by traits days to $50 \%$ flowering and flag leaf length.

High heritability accompanied with low genetic advance indicates of non-additive gene action. The high heritability is being exhibited due to the favorable influence of environment rather than genotypes and selection of such traits offers little scope for improvement by selection.

High heritability with low genetic advance was reported by Singh et al., (2006). Although Low estimates of genetic advance as percent mean was indicates the characters governed by non-additive gene action and heterosis breeding will be useful. Hence, making based on simple selection could be effective for improving those characters, as reported by (Abebe et al., 2017) and Hoque (2013) for panicle number per panicle.

\section{Correlation studies for yield components}

The degree of correlation among characteristics is an important factor, especially regarding economic and complex characteristics such as yield direct selection, which shows low effectiveness (Kiani, and Nematzadeh, 2012). Correlation coefficient is a measure of the degree association and relationship between two variables. It is important in plant breeding as it can be used for indirect selection.

The study of association between different characters may help the plant breeder to know how the improvement of one character will bring simultaneous changes in other characters (Adhikari, et al., .2018). In the present study, correlation coefficients among $\mathrm{F}_{2}$ individuals of the population, BPT5204 $\mathrm{x}$ WAB450 for yield and yield attributing characters are presented in Table 3.

Grain yield has a positive and significant correlation with plant height (0.360), days to $50 \%$ flowering (0.308), panicle exsertion (0.218) and straw yield (0.992). However, it has negative correlation with panicle exsertion (-0.176), flag leaf length (-0.077) and number of un-productive tillers per plant $(-0.017)$.

The plant height was positively correlated with panicle length $(0.120)$, panicle exertion (0.230), flag leaf length (0.161), flag leaf width (0.146) and number of tillers per plant (0.068), straw yield (0.374), grain yield (0.360) and root dry weight (0.078) but negatively associated with root volume (0.015 ) and negatively correlated with number 
of un-productive tillers per plant.

There was a significant positive correlation days to 50 per cent flowering with that of plant height $(0.333)$, grain yield $(0.308)$ and straw yield (0.326), but has significant negative correlation with number of tillers per plant (-0.193). A significant positive correlation of straw yield with days to 50 per cent flowering (0.326), plant height (0.374) and panicle exsertion (0.194), whereas, number of tillers showed significant negative correlation with days to 50 per cent flowering $(-0.193)$ followed by number of un-productive tillers per plant with number of productive tillers per plant $(-0.370)$ respectively.

Panicle exsertion showed positive significant correlation with plant height (0.230), similarly followed by traits viz., flag leaf width with panicle exsertion (0.233), total number of tillers with flag leaf length (0.215) and number of productive tillers with total number of tillers per plant (0.956) respectively. A strong correlation of grain yield with these traits indicated that, simultaneous improvement of these traits is possible.

Previous studies have mentioned similar findings (Abarshahr et al., 2011; Lanceras et al., 2004; Muhammed et al., 2007; Samonte et al., 1998). Mirza et al., (1992) reported positive correlation of number of panicles/m2 and grain yield with number of tillers/plant. Kumar et al., (1998) observed high positive correlation of grain yield with spikelet fertility.

\section{Path coefficient analysis}

The estimates of path coefficient analysis are furnished for yield and yield component characters are given in Table 4. Path coefficient analysis revealed that grain yield had direct effect or association from the traits viz., Days to $50 \%$ flowering (0.308), plant height (0.360), panicle exsertion (0.218) and straw yield per plant (0.992) and direct negative effect was recorded for traits namely, panicle length, flag leaf width, total number of tillers per plant and number of unproductive tillers per plant. An indirect positive effect belonging to grain yield per plant through flag leaf length (0.006) and number of productive tillers per plant $(0.011)$ was recorded (Table 4). These findings are in agreement with the results of Krishna (2007), Yogameenakshi and Vivekanandan (2010). These findings assist in imposing differential selection pressure during selection of genotypes for efficient root characters under moisture stress condition.

Kiani, and Nematzadeh, (2012) revealed that panicles per plant had the highest direct positive effect on grain yield and high direct positive effect of this character was nullified by the negative indirect effect of panicle length and non-filled grains per panicle, however its indirect effect via filled grains per panicle was high bringing the total correlation to $r=0.750$ with grain yield.

Results on importance of direct effect of panicles per plant were reported by several researchers (Bagheri et al., 2011; Kumar, 1992; Madhavilatha et al., 2005; Yadav and Bhushan, 2001; Yogameenakshi and Vivekanandan, 2010). Many researches the filled grains per panicle have been reported as effective trait with the highest direct effect on grain yield improvement (Bagheri et al., 2011; Ram, 1992; Sundaram and Palanisamy, 1994; Samonte et al., 1998).

But the magnitude of direct effect of the panicles per plant was high followed by filled grains per panicle, confirming the results of Basavaraja et al., (1997) and Kole et al., (2008). Then, appropriate selection indices should be formulated using these traits for yield improvement. 
Table.1 Trait means, range, standard deviation (SD), Standard error (SEm), Variance, Skewnes and Kurtosis for morphological and productivity traits in $\mathrm{F}_{2}$ population individuals of BPT5204 x WAB450

\begin{tabular}{|c|c|c|c|c|c|c|c|c|c|}
\hline Trait & Range & Minimum & Maximum & Mean & $\begin{array}{c}\text { Std. } \\
\text { Deviation }\end{array}$ & Std. Error & Variance & Skewness & Kurtosis \\
\hline DFF & 27.00 & 89.00 & 116.00 & 102.94 & 7.27 & 0.70 & 52.78 & -0.18 & -1.17 \\
\hline PH & 42.75 & 77.00 & 119.75 & 101.94 & 6.99 & 0.67 & 48.88 & -0.30 & 0.77 \\
\hline PaL & 12.55 & 14.45 & 27.00 & 22.30 & 2.60 & 0.25 & 6.73 & -0.37 & -0.21 \\
\hline PaE & 8.00 & 0.00 & 8.00 & 2.64 & 2.53 & 0.24 & 6.39 & 0.49 & -1.26 \\
\hline FLL & 16.00 & 19.00 & 35.00 & 27.03 & 3.33 & 0.32 & 11.07 & -0.03 & -0.30 \\
\hline FLW & 1.30 & 1.20 & 2.50 & 1.56 & 0.23 & 0.02 & 0.05 & 1.07 & 2.06 \\
\hline TNT & 14.00 & 5.00 & 19.00 & 11.22 & 2.71 & 0.26 & 7.34 & 0.57 & 0.46 \\
\hline NPT & 15.00 & 3.00 & 18.00 & 9.78 & 2.91 & 0.28 & 8.45 & 0.46 & 0.21 \\
\hline NUPT & 4.00 & 0.00 & 4.00 & 1.44 & 0.86 & 0.08 & 0.73 & 0.37 & -0.06 \\
\hline GY & 64.00 & 9.50 & 73.50 & 28.06 & 12.80 & 1.23 & 163.70 & 1.12 & 1.28 \\
\hline St.Y & 94.57 & 15.68 & 110.25 & 42.26 & 18.52 & 1.77 & 343.06 & 1.08 & 1.23 \\
\hline
\end{tabular}

\begin{tabular}{|c|c|c|c|}
\hline DFF & - Days to $50 \%$ flowering & $\mathrm{PH}$ & - $\quad$ Plant height at maturity $(\mathrm{cm})$ \\
\hline $\mathrm{PaE}$ & - Panicle exsertion $(\mathrm{cm})$ & FLL & - Flag leaf length $(\mathrm{cm})$ \\
\hline TNT & - Total number of tillers/ plant & NPT & - Number of productive tillers/ plant \\
\hline GY & - $\quad$ Grain yield per plant $(\mathrm{g})$ & St.Y & - $\quad$ Straw yield per plant $(\mathrm{g})$ \\
\hline
\end{tabular}

\author{
$\mathrm{PaL} \quad-\quad$ Panicle length $(\mathrm{cm})$ \\ FLW - Flag leaf width $(\mathrm{cm})$ \\ NUPT - Number of un-productive tillers/plant
}


Table.2 Genetic parameters of $109 \mathrm{~F}_{2}$ plants of BPT x WAB450 for yield and yield attributing characters

\begin{tabular}{|c|c|c|c|c|c|c|c|}
\hline Traits & GCV & PCV & $h^{2}(b s)$ & $\begin{array}{c}\text { Genetic } \\
\text { Advance } \\
5 \%\end{array}$ & $\begin{array}{c}\text { Genetic } \\
\text { Advance } 1 \%\end{array}$ & $\begin{array}{c}\text { Gen.Adv. as\% } \\
\text { of Mean } 5 \%\end{array}$ & $\begin{array}{c}\text { Gen. Adv. as } \\
\% \text { of Mean } \\
1 \%\end{array}$ \\
\hline DFF & 7.058 & 18.712 & 99.00 & 0.564 & 0.723 & 0.548 & 0.703 \\
\hline PH & 6.858 & 6.877 & 99.40 & 14.362 & 18.406 & 14.089 & 18.055 \\
\hline PaL & 11.635 & 16.601 & 49.10 & 3.746 & 4.801 & 16.799 & 21.529 \\
\hline PaE & 14.790 & 18.571 & 37.80 & 4.594 & 5.887 & 17.409 & 22.311 \\
\hline FLL & 12.309 & 13.491 & 83.20 & 6.253 & 8.014 & 23.132 & 29.645 \\
\hline FLW & 14.431 & 15.840 & 01.60 & 0.060 & 0.076 & 3.817 & 4.891 \\
\hline TNT & 24.146 & 24.194 & 99.60 & 5.570 & 7.138 & 49.643 & 63.620 \\
\hline NPT & 29.725 & 34.151 & 75.80 & 5.212 & 6.680 & 53.298 & 68.305 \\
\hline NUPT & 5.93 & 12.536 & 22.40 & 0.833 & 1.068 & 57.836 & 74.119 \\
\hline GY & 45.605 & 45.662 & 99.80 & 26.324 & 33.736 & 93.831 & 120.025 \\
\hline St.Y & 43.833 & 44.642 & 96.40 & 37.464 & 48.012 & 88.661 & 113.623 \\
\hline
\end{tabular}

\begin{tabular}{|c|c|c|c|c|c|c|}
\hline DFF & - $\quad$ Days to $50 \%$ flowering & PH & - $\quad$ Plant height at maturity $(\mathrm{cm})$ & $\mathrm{PaL}$ & - & Panicle length $(\mathrm{cm})$ \\
\hline $\mathrm{PaE}$ & - Panicle exsertion $(\mathrm{cm})$ & FLL & Flag leaf length $(\mathrm{cm})$ & FLW & - & Flag leaf width $(\mathrm{cm})$ \\
\hline TNT & - $\quad$ Total number of tillers/ plant & NPT & - $\quad$ Number of productive tillers/ plant & NUPT & - & Number of un-productive tillers/plant \\
\hline GY & - $\quad$ Grain yield per plant (g) & St.Y & - $\quad$ Straw yield per plant $(\mathrm{g})$ & & & \\
\hline
\end{tabular}


Table.3 Phenotypic correlations among grain yield and yield components in $\mathrm{F}_{2}$ progenies of BPT5204 x WAB450

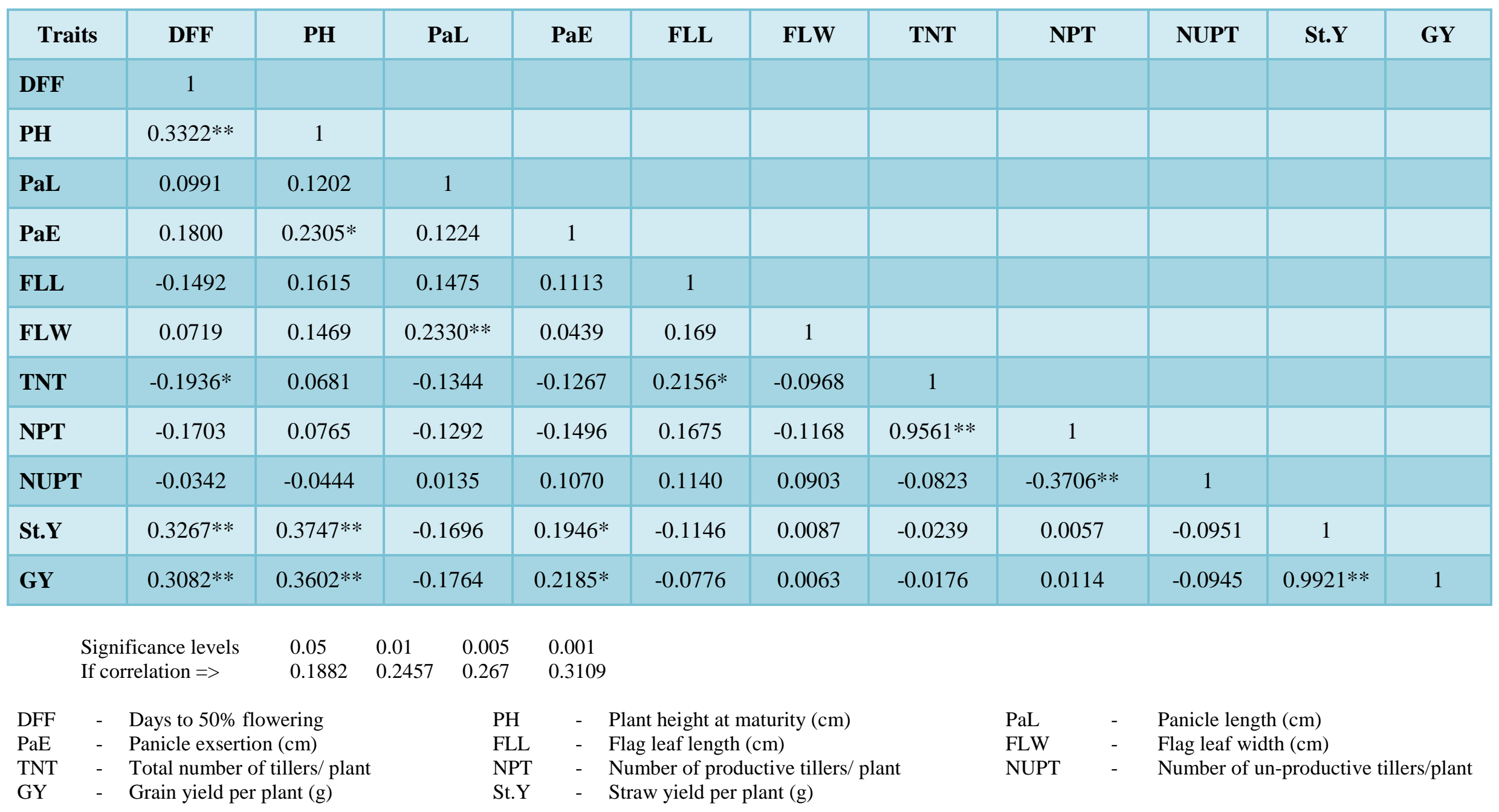


Table.4 Path analysis of yield component on grain yield in BPT5204 x WAB450

\begin{tabular}{|c|c|c|c|c|c|c|c|c|c|c|}
\hline Traits & DFF & PH & PaL & PaE & FLL & FLW & TNT & NPT & NUPT & St.Y \\
\hline DFF & -0.0094 & -0.0031 & -0.0009 & -0.0017 & 0.0014 & -0.0007 & 0.0018 & 0.0016 & 0.0003 & -0.0031 \\
\hline PH & -0.0075 & -0.0227 & -0.0027 & -0.0052 & -0.0037 & -0.0033 & -0.0015 & -0.0017 & 0.0010 & -0.0085 \\
\hline PaL & -0.0012 & -0.0014 & -0.0119 & -0.0015 & -0.0018 & -0.0028 & 0.0016 & 0.0015 & -0.0002 & 0.0020 \\
\hline PaE & 0.0052 & 0.0066 & 0.0035 & 0.0286 & 0.0032 & 0.0013 & -0.0036 & -0.0043 & 0.0031 & 0.0056 \\
\hline FLL & -0.0059 & 0.0064 & 0.0058 & 0.0044 & 0.0396 & 0.0067 & 0.0085 & 0.0066 & 0.0045 & -0.0045 \\
\hline FLW & -0.0002 & -0.0004 & -0.0007 & -0.0001 & -0.0005 & -0.0030 & 0.0003 & 0.0003 & -0.0003 & 0.0000 \\
\hline TNT & 0.5411 & -0.1903 & 0.3757 & 0.3543 & -0.6028 & 0.2707 & -2.7957 & -2.6731 & 0.2300 & 0.0668 \\
\hline NPT & -0.5107 & 0.2294 & -0.3875 & -0.4484 & 0.5021 & -0.3501 & 2.8668 & 2.9983 & -1.1112 & 0.0170 \\
\hline NUPT & -0.0298 & -0.0388 & 0.0118 & 0.0934 & 0.0995 & 0.0788 & -0.0718 & -0.3236 & 0.8732 & -0.0830 \\
\hline St.Y & 0.3267 & 0.3747 & -0.1696 & 0.1946 & -0.1146 & 0.0087 & -0.0239 & 0.0057 & -0.0950 & 0.9999 \\
\hline GY & $0.3082 * *$ & $0.3602 * *$ & -0.1764 & $0.2185^{*}$ & -0.0776 & 0.0063 & -0.0176 & 0.0114 & -0.0945 & $0.9921 * *$ \\
\hline
\end{tabular}

R SQUARE $=0.9870$ RESIDUAL EFFECT $=0.1139$

\begin{tabular}{|c|c|c|c|}
\hline DFF & Days to $50 \%$ flowering & $\mathrm{PH}$ & Plant height at maturity $(\mathrm{cm})$ \\
\hline $\mathrm{PaE}$ & Panicle exsertion $(\mathrm{cm})$ & FLL & Flag leaf length $(\mathrm{cm})$ \\
\hline TNT & Total number of tillers/ plant & NPT & Number of productive tillers/ plant \\
\hline GY & - $\quad$ Grain yield per plant $(\mathrm{g})$ & St.Y & Straw yield per plant (g) \\
\hline
\end{tabular}

$\mathrm{PaL} \quad$ - $\quad$ Panicle length $(\mathrm{cm})$

FLW - Flag leaf width $(\mathrm{cm})$

NUPT - Number of un-productive tillers/plant 


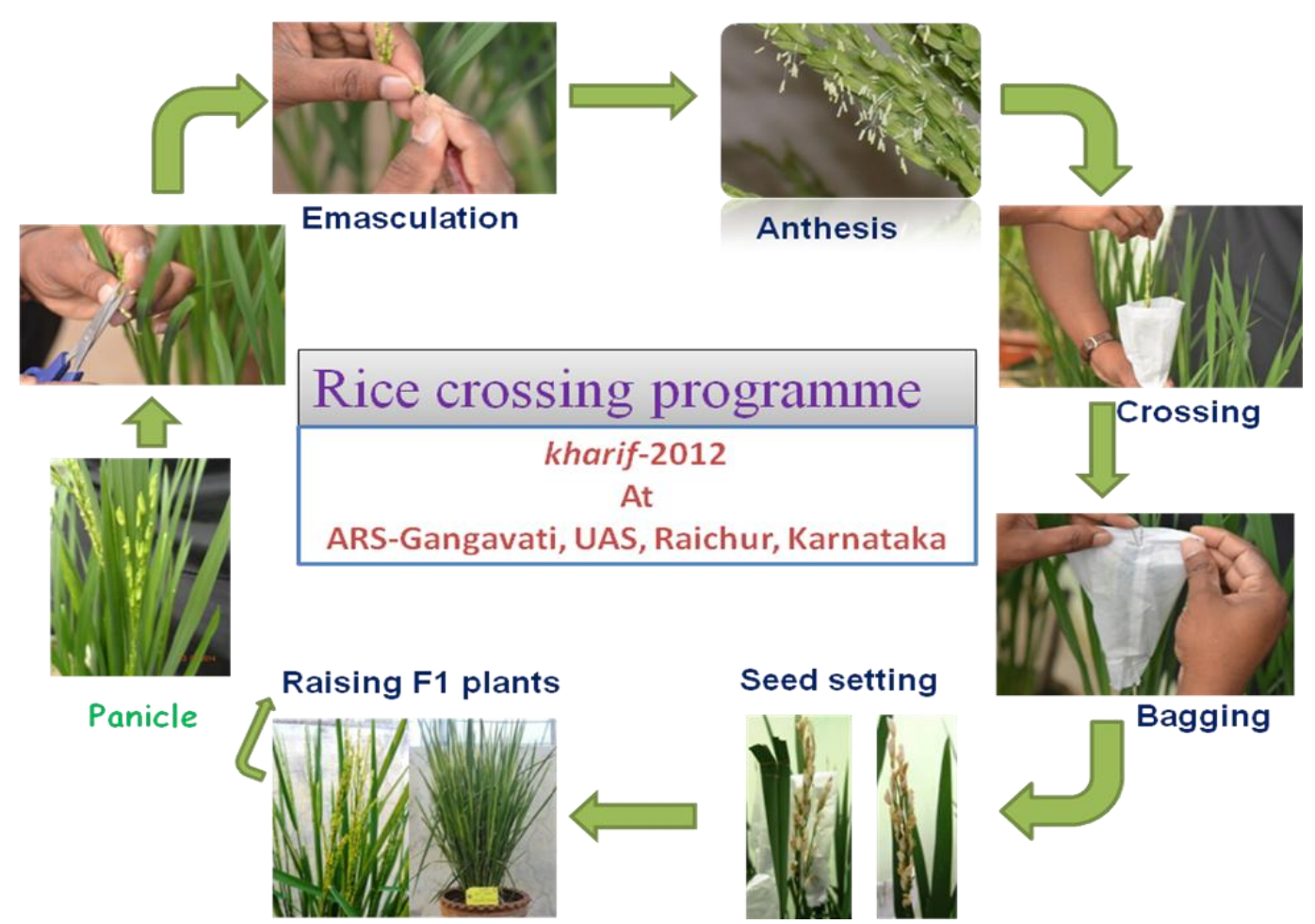

Figure.1 Pictorial view of Crossing programme with tools used in development of F2 population of the cross BPT $5204 \times$ WAB 450
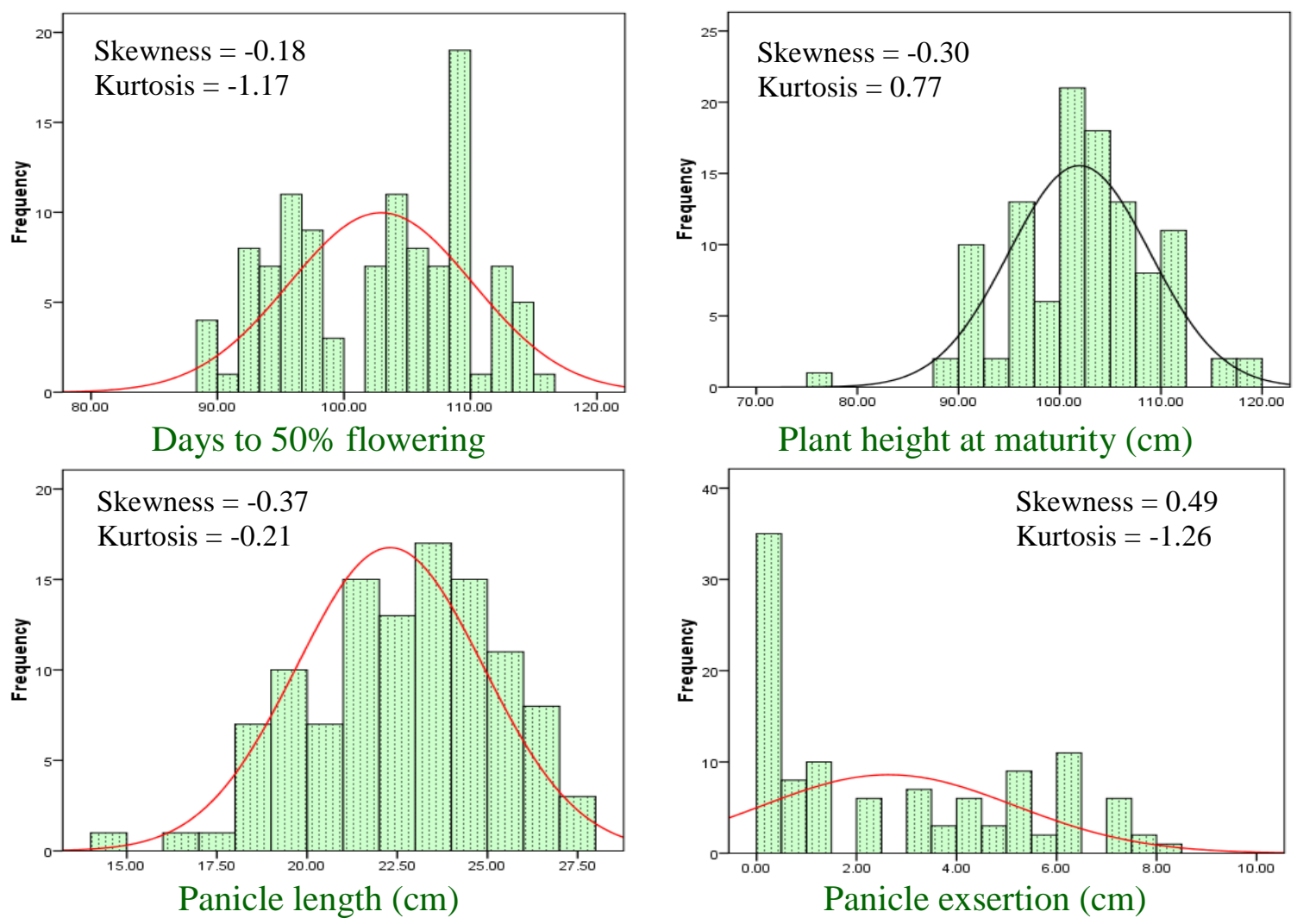

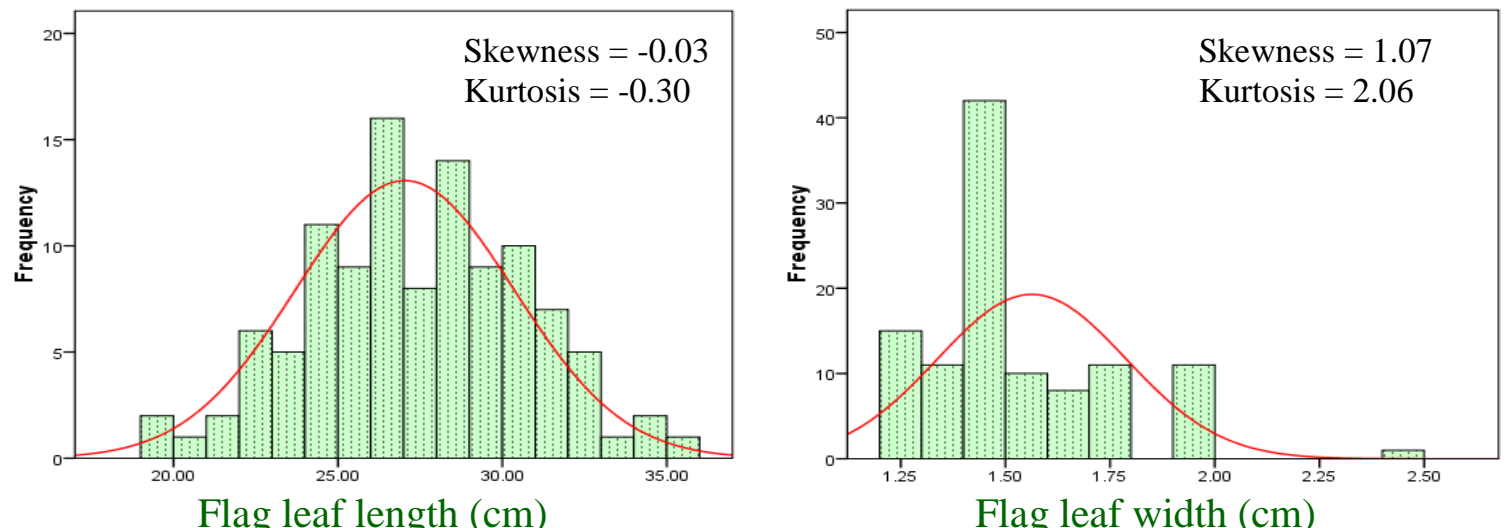

Flag leaf width $(\mathrm{cm})$
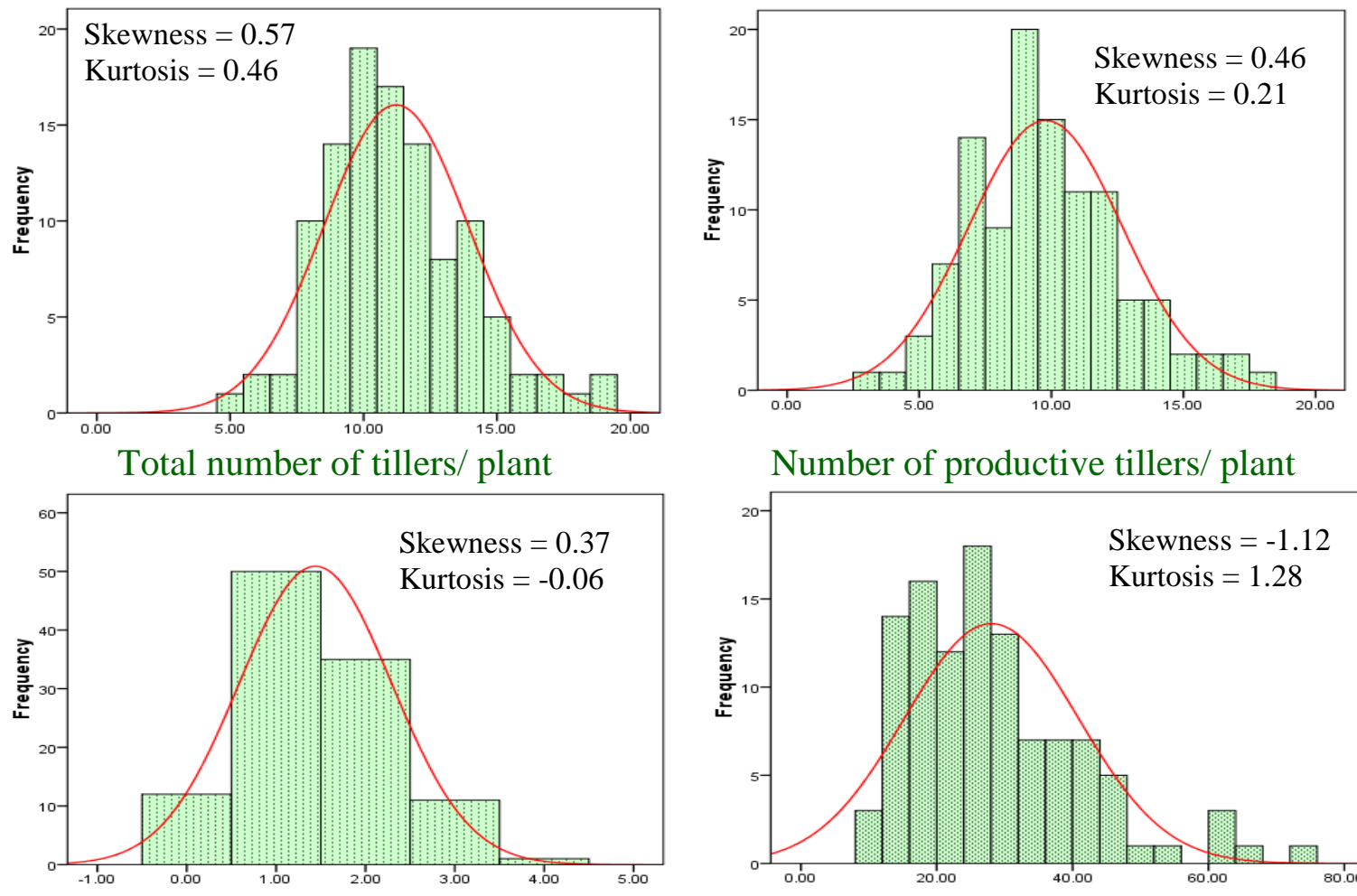

Number of productive tillers/ plant
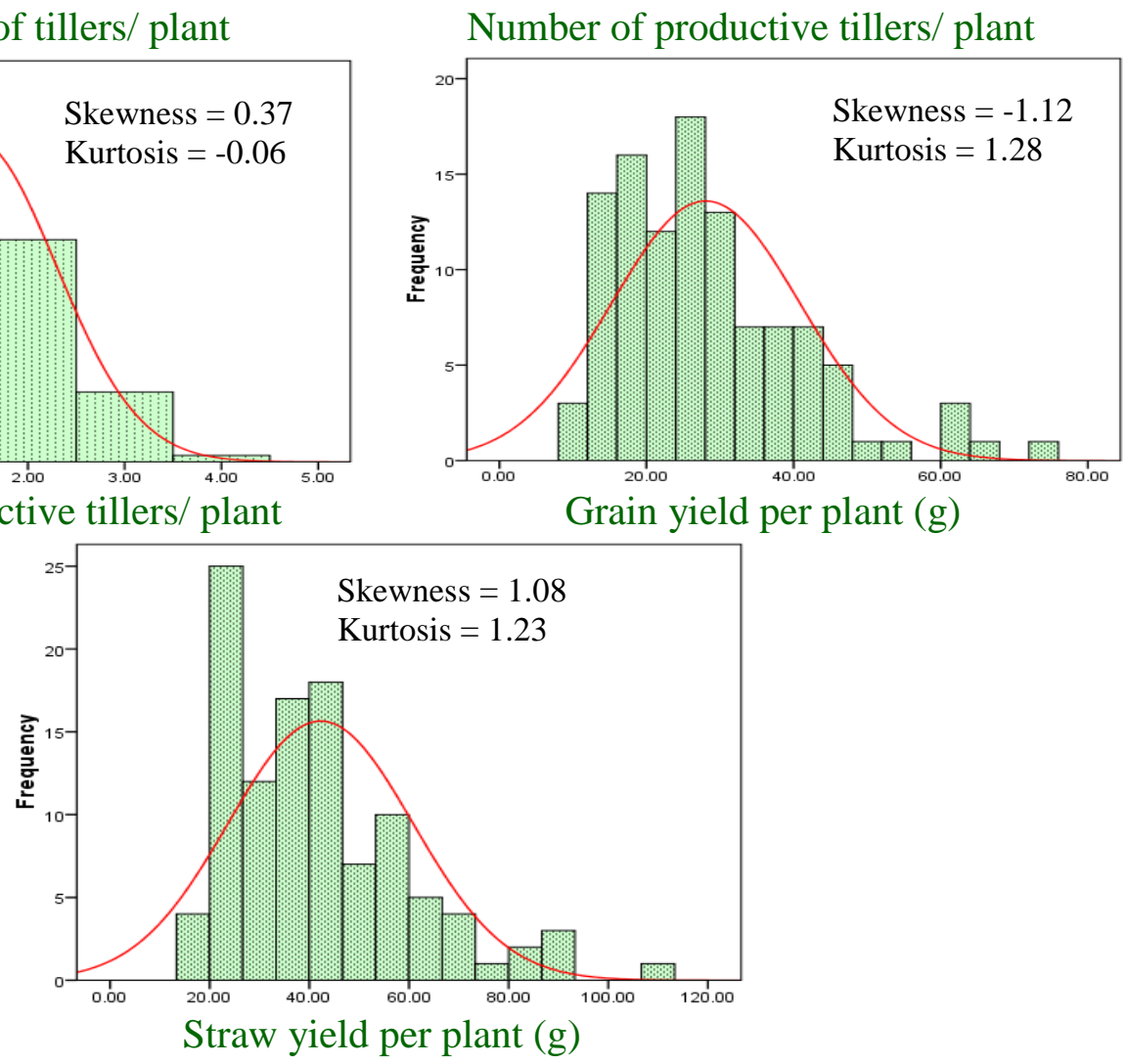

Figure.2 Frequency distribution for yield and yield attributing component traits in $\mathrm{F}_{2}$ population of BPT5204 x WAB450 


\section{Skewness and Kurtosis}

The results from the present investigation was revealed that positively skewed and highly skewed was estimated in traits viz., panicle exsertion (1.07), total number of tillers per plant (1.16), total productive tillers per plan(1.12) and straw yield per plant (1.03). Similarly, number of unproductive tillers per plant (0.56) and grain yield per plant $(0.85)$ was recorded positive skewed and moderately skewed followed by negatively skewness for plant height (-0.50), panicle length (-0.33), flag leaf width (-1.09). The data of fairly symmetrical was recorded in days to $50 \%$ flowering (0.13) and flag leaf length (0.06) traits under study. The data on skewness and kurtosis was presented in the Table 1.

In the present study, majority traits were recorded platykurtic type of kurtosis (Kurtosis <3) where distribution is shorter, tails are thinner than the normal distribution and he peak is lower and broader than Mesokurtic, which means that data are light-tailed or lack of outliers except flag leaf length which had Leptokurtic (Kurtosis > 3) where distribution is longer, tails are fatter, peak is higher and sharper than Mesokurtic, which means that data are heavy-tailed or profusion of outliers. The graphical representation of frequency distribution, skewness and kurtosis for yield and yield attributing component traits in $\mathrm{F}_{2}$ population of BPT5204 x WAB450 were presented in Figure 2.

Mamatha et al., (2019) revealed from their studies in 'Rajamudi $\times$ BR-2655' and 'Rathnachoodi $\times$ BR-2655' crosses of rice that platykurtic and positively skewed distribution indicated dominance based complementary gene interaction involving presence of large number of genes having decreasing effect on the trait days to $50 \%$ flowering in both the populations. The trait plant height appeared to controlled by few segregating genes with majority of them exhibiting decreasing effect and dominance based complementary gene interaction as indicated by the leptokurtic and negatively skewed. The platykurtic and negatively skewed distribution indicated dominance based complementary gene interaction involving presence of large number of genes having decreasing effect in the inheritance of grains per panicle.

Results of the investigation indicates that selection will be effective in the test materials used in this study as revealed by the significant substantial variations among the F2 individuals for all the characters observed. These lines have been actively utilized in further breeding program. Traits showing high heritability coupled with high genetic advance (as per cent of mean) indicating that these characters attributable to additive gene effects. Yield can be improved directly by effecting selection for the traits manifested positive and significant association viz., plant height, days to $50 \%$ flowering panicle exsertion and straw yield.

\section{References}

Abarshahr M, Rabiei B, Samizadeh-Lahigi H. Genetic variability, correlation and path analysis in rice under optimum and stress irrigation regimes. Nat. Sci. Biol. 2011; 3(1):134-142.

Abebe T, Alamerew S, Tulu L. Genetic Variability, Heritability and Genetic Advance for Yield and its Related Traits in Rainfed Lowland Rice (Oryza sativa L.) Genotypes at Fogera and Pawe, Ethiopia. Adv. Crop Sci. Tech. 2017; 5:2329-8863.

Adhikari BN, Joshi BP, Shrestha J. Bhatta NR. Genetic variability, heritability, genetic advance and correlation among yield and yield components of rice (Oryza sativa L.). Journal of agriculture and Natural Resources, 2018; 1(1): 149-160.

Ananadrao SD, Singh CM, Suresh BG, Lavanya GR. Evaluation of rice hybrids for yield and 
yield component characters under North east plain Zone, The Allahabad Farmer, 2011; 67(1): 63-68.

Anilkumar CV 2008. Genetic analysis of economic traits in segregating population of Rice (Oryza sativa L.). M.Sc. (Ag.) Thesis (Unpubl.), TNAU, Coimbatore. 2018.

Ansari A, Julfiquar, AW, Rasul, MG, Hasan MJ, Rahman MM. Genetic parameter, correlation and path analysis for yield and yield related traits in some maintainer lines of hybrid rice (Oryza sativa L). Ecofriendly Agril. J. 2010; 3(2): 8995.

Arpita Shrivastava DK, Mishra GK, Koutu SK, Singh, A. Heritability and genetic advance estimation from parental lines of hybrid rice. International Journal of Scientific Research. 2014; 3(7):11-13.

Ashok KT, Singh SK, Sharma A, and Bhati PK. Appraisal of genetic variability for yield and its component characters in rice (Oryza Sativa L.). Biolife. 2013; 1(3):84-89.

Augustina UA, Iwunor OP, Ijeoma OR. Heritability and character correlation among some rice genotypes for yield and yield components. J. Plant Breed. Genet., 2013; 1(2):73-84.

Bagheri N, Babaeian-Jelodar N, Pasha A. Path coefficient analysis for yield and yield components in diverse rice (Oryza sativa L.) genotypes. Bih. Biol. 2011; 5:32-35.

Basavaraja P, Rudradhya M, Kulkarni RS. Genetic variability, correlation and path analysis of yield components in two F4 population of fine grained rice. Mysore J. Agric. Sci. 1997; 1:1-6.

Bekele B..D, Rakhi S, Naveen GK, Kundur PJ, Shashidhar HE. Estimation of genetic variability and correlation studies for grain zinc concentrations and yield related traits in selected rice (Oryza sativa L.) Genotypes. Asian J. Exp. Biol. Sci. 2013; 4(3), 345-351.

Bhadru DL, Krishna, Md. Latheef Pasha and R.B. Muralidhar Naik RB. Effect of environment on genetic parameters of hybrid rice. International Journal of Applied Biology and Pharmaceutical Technology. 2012; 3(2):183-187.

Bhuvaneswari S, Kumar S, Singh M, Takhellambam S, Shashidhar KSY, Singh
R. Genetic Variability and Association Studies on Grain Yield Components in F2 Populations of Black Rice (Oryza sativa L.) of Manipur. Ind. J Hill Farm. 2015; 28:8589.

Cochran and Snedecor GW. Statistical methods. The Iowa State University Press, Acer, Iowa, USA, 1961; pp 388.

El-Badri A, Anis G, Hefeina A, Barutcular C, ElSabagh A. Genetic variability in F2 generation for some physio-morphological characteristics in Rice. J. Agr. Biotech., 2016; 01(02):68-75.

Federer WT. Experimental Design: Theory and Application. McMillan, New York. 1977.

Gangashetty PP, Salimath, Hanamaratti N. Genetic variability studies in genetically diverse non-basmati local Aromatic genotypes of rice (Oryza sativa L). Rice Genomics and Genetics. 2013; 4(2): 4-8.

Hanson CH, Robinson HF, Comstock R. E., Biometrical studies in yield in segregating populations of Korean Laspedez. Agron, J., 1956; 48: 267-282.

Hefena AG, Sultan MS, Abdel-Moneam MA, Hammoud SA, Celaleddin B, El-Sabagh A. Genetic variability, heritability and genetic advance for yield and associated traits in F2 rice population, J. Agril. Biotech. 2016; 1(2): 49-58.

Hoque A. Morpho-physiologicaland molecular characterization of rice (Oryza sativa L.) advanced breeding lines for earliness. Doctoral dissertation presented to Sokoine University of Agriculture, Morogoro, Tanzania, 2013.

Johnson HW, HF, Robinson, Comstock RE. Genotypic and phenotypic correlations in soybeans and their implications in selection. Agron. J. 1955; 47: 477-483.

Karthikeyan PY, Anbuselvam R, Elangaimannan, Venkatesan M. Variability and heritability studies in rice(Oryza sativa L.) under coastal salinity,J.Plant Breed. 2010; 1(2):196-198.

Khare R, A. K. Singh AK, Eram S, and Singh PK. Genetic variability, association and diversity analysis in upland rice (Oryza sativa L). SAARC J. Agri. 2014; 12(2): 4051.

Khush GS, Virk PS. Rice breeding Achievements 
and Future Strategies. Crop Improv. 2005; 27: 115-144.

Kiani G, Nematzadeh G. 2012, Correlation and path coefficient studies in $\mathrm{F} 2$ populations of rice. Not. Sci. Biol., 2012; 4(2):124-127.

Kole PC, Chakraborty NR, Bhat JS. Analysis of variability, correlation and path coefficient in induced mutants of aromatic non-basmati rice, Tropical agriculture research and extension. 2008; 11: 60-64.

Kole PC, Hasib KM. Correlation and regression analysis in scented rice. Madras Agricultural Journal. 2008; 95(1-6): 178182.

Krishna JV. Genetic assessment of RILs of of IR50/Monoberekan for drought, nutritional parameters and validation of root specific markers in rice (Oryza sativa L.). Ph.D. Thesis, Univ. Agril. Sci., Bangalore. 2007.

Kumar CRA. Variability and character association studies in upland rice. Oryza. 1992; 29:3134.

Kumar GS, Mahadevappa M, Rudraradhya M. Studies on genetic variability, correlation and path analysis in rice during winter across the locations. Karnataka Journal of Agricultural Science. 1998; 11(1): 73-77.

Kundu A, Senapati BK, Bakshi A, Mandal GS, Genetic variability of panicle characters in tall indica aman rice, Oryza. 2008; 45(4): 320-323.

Lanceras J, Pantuwan G, Jongdee G, Toojinda T. Quantitative trait loci associated with drought tolerance at reproductive stage in rice. Plant Physiol. 2004; 135: 384-399.

Laxuman P, Salimath M, Shashidhar HE, Mohankumar HD, Patil SS, H. M. Vamadeviha HM, Janagoudar BS. Analysis of genetic variability in interspecific backcross inbred lines in rice (Oryza sativa L.), Karnataka Journal of Agricultural Sciences. 2010; 23(4), 563-565.

Lush JL. Heritability of quantitative character in farm animals. Hertditas (suppl.). 1949; 35: 256-264.

Madhavilatha L, Reddi Sekhar M, Suneetha Y, Srinivas T. (2005). Genetic variability, correlation and path analysis for yield and quality traits in rice (Oryza sativa L.). Res Crops. 2005; 6(3):527-534.

Manjunatha B, Malleshappa C, Niranjanakumar
B. Studies on variability, heritability and genetic advance for quantitative traits in rice (Oryza sativa L.). International Journal of Agricultural Sciences, 2018; 10(11):6192-6194.

Mirza MJ, Faiz FA, Mazid. A. Correlation studies and path analysis of plant height, yield and yield components in rice (Oryza sativa $\mathrm{L}$ ). Sarhad J. Agric. 1992; 8(6): 647-653.

Muhammed B, Asif AK, Anjuman A, Yusuf Z, Muhammad A. Path analysis of some leaf and panicle traits affecting grain yield in doubled haploid lines of rice (Oryza sativa L.). J Agric Res. 2007; 45:248-252.

Ogunbayo SA, M.Sie DK, Ojo KA, Sanni MG, Akinwale B, Toulou A, Shittu, EO, Idehen AR, Popoola IO, Daniel GB, Gregorio. Genetic Variation and Heritability of yield and related traits in promising rice genotypes (Oryza sativa L.), Journal of plant breeding and crop sciences. 2014; 6(11):153-159.

Padmaja D, Rao, KR, Subba LV, Padma V. Studies on variability, heritability and genetic advance for quantitative characters in rice (Oryza sativa L.), Indian Journalof Plant Genetic Resources. 2008; 21(3), 71 84.

Parmeshwar KUS, Sharma D, Sahu P, Singh S, Chaudhary PR, Sao FC. Assessment of genetic parameters for various quantitative and qualitative traits in hybrid rice (Oryza sativa L.). National Academy of Agricultural Science. 2015; 33(1):97-102.

Prajapati M, Singh CM, Suresh BG, G.R. Lavanya GR, Jadhav P. Genetic parameters for grain yield and its component characters in rice. Elec. J. Pl. Bred., 2011; 2(2):235-238.

Pratap N, P.K. Singh PK, Shekhar R, Soni SK, Mall AK. Genetic variability, character association and diversity analyses for economic traits in rice (Oryza sativa L.). SAARC Journal of Agriculture. 2012; 10(2): 83-94.

Priyanka Yadav NR, Rangare P, John Anurag, Chaurasia AK. Quantitative analysis of rice (Oryza sativa L.) in Allahabad Agro Climate Zone. Journal of Rice Research. 2011; 3(1):16-18.

Ram T. Character association and path coefficient analysis in rice hybrids and their parents. J. 
Andaman Sci. Assoc. 1992; 8:26-29.

Rani CS, Anandakumar CR, Raveendran M, Subramanian KS, Robin S, Genetic variability studies and multivariate analysis in F2 segregating populations involving medicinal rice (Oryza sativa L.) cultivar Kavuni. Int. J. Agril. Sci., 2016; 8 (15): 1733-1735.

Rema Bai NR, Ahmed. R, Devika, Joseph CA. Genetic variability and association of characters in medium duration rice genotype. Oryza. 1992; 29(1): 19-22.

Robinson HF, Comstock RE, Harvey PH, Estimation of heritability and degree of dominance in Corn. Agron, J., 1949; 41: 353-359.

Sala M. Rice breeding for biofortification with high iron and zinc content in segregating population. M.Sc. (Ag.), Thesis (Unpubl.), TNAU, Madurai. 2012.

Samonte SO, Wilson LT, McClung A. Path analysis of yield and yield-related traits of fifteen diverse rice genotypes. Crop Sci. 1998; 38:1130-1136.

Sangeetha LNE. Genetic variability studies for grain yield and grain quality traits in $\mathrm{F} 2$ and F3 population of rice (Oryza sativa L.). M.Sc. (Ag.) Thesis (Unpubl.), TNAU, Madurai. 2013.

Savitha P, Ushakumari R, Genetic variability studies in F2 and F3 segregating generations for yield and its components in rice (Oryza sativa L.). Indian J. Sci. and Tech. 2015; 8(17):1-7.

Shashidhara N, Biradar H, Hittalmani S. Qualitative and Quantitative Genetic Variations in the F2 Inter Varietal Cross of
Rice (Oryza sativa L.) under Aerobic Condition and Parental Polymorphism Survey. Int. J Curr. Micro. App. Sci. 2017; 6:2215-2225.

Shrivastava A, Mishra DK, Koutu GK. Estimation of genetic parameters of variability for yield and its attributing traits in parental lines of hybrid rice. Plant Arch. 2015; 15:571-574.

Singh SK, Singh, CM, G.M.Gil GM. Assessment of genetic variability for yield and its component character in rice. Research In plant Biology. 2011. 1(4): 73-76.

Sundaram T, Palanisamy S. Path analysis in early rice (Oryza sativa L.). Madras Agric. J. 1994; 81:28-29.

Umesh Jaiswal HK, Sravan T, Waza SA, Bhardwaj R. Estimation of genetic variability, heritability and genetic advance for yield and quality traits in some indigenous Basmati rice (Oryza sativa $\mathrm{L}$ ) genotypes. Int. J Farm Sci. 2015; 5:32-40.

Webber CR, Moorthy BR. Heritable and nonheritable relationship and variability of content and agronomic characters in the segregation of Soybean cross. Agron. J., 1952; 4: 202-209.

Yadav RS, Bhushan C. Effect of moisture stress on growth and yield in rice genotypes. Ind $\mathrm{J}$ Agricult Res. 2001; 2:104-107.

Yates F. Statistical methods for agricultural workers, ICAR, Pub. 1965; pp. 72-83.

Yogameenakshi P, Vivekanandan P. Association analysis in $F_{1}$ and $F_{2}$ generations of rice under reproductive stage drought stress. Electronic J. Plant Breeding, 2010; 1: 890898.

\section{How to cite this article:}

Boranayaka. M. B., R. Lokesha, H. C. Latha and Mahanth Shivayogayya. K. 2020. Genetic Variability, Character Association, Frequency and Normality Distribution Studies for F2 Population of BPT-5204 $\mathrm{x}$ WAB-450 Cross in Rice (Oryza sativa L.). Int.J.Curr.Microbiol.App.Sci. 9(05): 278-295. doi: https://doi.org/10.20546/ijcmas.2020.905.031 